Stream: Culture/Politics/Technology, 6(1): 53-55

http://journals.sfu.ca/cpt/index.php/stream/index

\title{
Publicly Funding Journalism in an Age when Everyone is a journalist
}

\section{Amanda Oye}

Department of Communication Studies, York University

With access to a computer and an Internet connection, anyone can act as a journalist today. More than just acting as journalists however, people are acting as publishers, as curators of the news, as editors and as opinion leaders and they exist in addition to the legacy media organizations that provide news through more traditional mediums. The sheer volume of content now available is undeniable. The question then is: Should government be involved in funding any of it?

The Canadian government funds the news, in part, by providing a parliamentary appropriation to the Canadian Broadcasting Corporation (CBC), the country's public broadcaster. The CBC is mandated by the 1991 Broadcasting Act to "provide radio and television services incorporating a wide range of programming that informs, enlightens and entertains" (Canadian Broadcasting Act, 1991, p. 5). Part of fulfilling that mandate is currently interpreted to mean that the CBC is to broadcast local, national and international news. News is only part of what the CBC is funded to produce, but it is a large part of what it does.

As a public broadcaster, the $\mathrm{CBC}$ is necessarily propelled by a different logic than broadcasters that operate using commercial funding models. A key difference that causes this is that public broadcasters, generally speaking, are funded through different means. "While commercial broadcasters have to rely primarily on market forces to survive, public service media tend to be funded by a variety of mechanisms either directly or indirectly by state subsidy" (Cushion, 2012, p. 21). Simply put, while there is no universal way by which all public broadcasters are funded, they are all funded, at least in part, through funds from the state (Jakubowicz, 2006; Cushion, 2012; Debrett, 2010). Another important distinction between commercial and public broadcasting that comes from the financial differences of each is that commercial broadcasters speak to consumers while public broadcasters speak to citizens (Rowland, 2013, p. 8). Spending public funds on broadcasting is often justified because of market failure. Market failure happens when private industry either cannot or will not provide a necessary service (Ward, 2006). This argument was more easily accepted when broadcasting was first established, spectrum was scarce, and public broadcasters often operated as monopoly broadcasters (Jakubowicz, 2006).

The last decade, however, has seen an incredible increase in the amount of information available and change in the way that it is consumed. "News is more readily available than ever before and, whether watching breaking news unfold on television, listening to live radio commentary or receiving a tweet, text or email, information has never been more instant or up to date, there at the flick of a switch" (Cushion, 2012, p. 1). This has changed the way that people consume news, the way that journalists report the news and the way that publishers publish the news. So much has changed in the news industry in fact, that the lines between who is playing each role has become blurred. Consumers, journalists, publishers, - people are now playing any combination of roles thanks to new, easily accessible technology. Social media sites including Facebook, Youtube and Twitter, provide citizens with platforms through which they can express their opinions and debate topics of public and private interest. Through the use of these technologies "the viewing public, who had been passive recipients of television and radio broadcasts for most of the twentieth century, were transforming themselves into the masters of content. On the Web the user was now king" (Ryan, 2010, p. 141). This new position taken on by audiences came with the development of Web 2.0 and social media, which allow users to actively participate in the production of news instead of idly consuming it. All of this content now being created by users is in addition to the content still being created and published by legacy media, which utilizes many of the same technologies, as well as more traditional technologies, to reach their audiences. 
If public service broadcasters, or more broadly put, public service media, exists to correct market failure, the only way to justify their continued existence would be to suggest a role for them to play that the market does not currently fulfill. In an oversaturated news media environment, what is the role of public service broadcasters in providing news? What justification is there for government to be funding media organizations to provide news content when there is already a vast array of sources of information available? Public funding for news broadcasting stands to serve several unique purposes that can be placed broadly into two categories: quality content and unprofitable content.

The first category, quality content, is based on the notion that public service media should provide and set the tone for a certain level of quality content in the overall news system. Publicly funded media can "compete strongly in conventional news coverage to encourage private broadcasters to be the best they can be" (Rowland, 2013, p. 65). This is achievable by public service media specifically because public funding helps to alleviate one of the fundamental problems that commercial journalism faces - commercial influence. The problem with commercial news is the influence that advertising can have on content. "In recent years journalism has been subject to a good deal of criticism for pursuing news that is more entertaining than informative, or for compromising on values of accuracy and balance to boost ratings and remain competitive" (Cushion, 2012, p. 44).

The second category, unprofitable content, is based on the notion that public funding should be provided to pay for necessary journalism that commercial organizations will not undertake. This can included "cover[ing] stories of high importance but low audience appeal, such as ceremonial events of national significance" and providing a consistent historical record (Rowland, 2013, p. 65). It can also include providing depth and context or stories where private broadcasters wont (Rowland, 2013, p. 65). This is a role that public broadcasters have been shown to be good at playing. Stephen Cushion's (2013) book, The Democratic Value of News, which looks at whether or not democratic value can be found in various news models in this information-rich society, found that "viewers tuning into or surfing the websites of public and commercial news media will most likely find that in day-to-day coverage public service media reflect a more diverse and in-depth picture of the world than their commercial counterparts" (p. 205). He also found "regular exposure to regulated public service broadcast news appears to increase people's knowledge about the world" (Cushion, 2012, p. 186). Cushion (2012) does not argue that public service media are without fault or that they are not completely immune from commercial pressures, only that public media are more likely to have more in-depth coverage.

Both quality content beyond what is typically afforded by commercial ventures and depth and variety of coverage considered to be unprofitable are important to Canada's news system and the continued preservation of Canada's culture and history. Even with the abundance of voices screaming across the Internet, there are still matters of importance to Canadians that are not commercially viable and are either underrepresented or uncovered by commercial news organizations. While the $\mathrm{CBC}$ is not perfect and is certainly going through difficult financial times, it is important to consider what the Canadian news system gains from having the CBC participate in the production of news, and perhaps more importantly, what it stands to lose should it cease to be a part of it.

\section{References}

Broadcasting Act. (S.C. 1991, c. 11). Retrieved from Justice Laws website: http://lawslois.justice.gc.ca/eng/acts/B-9.01/

Cushion, S. (2012). The democratic value of news: Why public service media matter. Basingstoke: Palgrave Macmillan.

Debrett, M. (2010). Reinventing public service television for the digital future. Bristol, UK: Intellect. Jakubowicz, K. (2006). Keep the essance, change (almost) everything else: Redefining PSB for the 21st century. In I. Banerjee, \& K. Seneviratne (Eds.), Pubic service broadcasting and the age of 
globalization (pp. 94-116). Jurong Point, Signapore: Asian Media Information and Communication Centre.

Rowland, Wade. (2013). Saving the CBC Balancing Profit and Public Service. Quebec: Linda Leith Publishing Inc.

Ryan, J. (2010). A History of the Internet and the Digital Future. London: Reaktion Books Ltd.

Ward, D. (2006). Can the makert provide? Public service media, market failure and public goods. In C. S. Nissen (Ed.), Making a difference (pp. 51-63). Eastleigh, UK: John Libbey Publishing.

\section{About the Author}

Amanda Oye is PHD student in the Communication \& Culture program offered jointly through Ryerson University and York University. She completed her MA in Communication at School of Communication, Simon Fraser University. Her major research interests are public broadcasting and public policy. 